Irwan, A. W. • T. Nurmala

\title{
Pengaruh pupuk hayati majemuk dan pupuk fosfor terhadap pertumbuhan dan hasil kedelai di inceptisol Jatinangor
}

\section{Effect of compound-biological-fertilizers and phosphor on growth and yield of soybean on Inceptisols Jatinangor}

Diterima : 8 November 2018/Disetujui : 23 Desember 2018 / Dipublikasikan : 31 Desember 2018

CDepartment of Crop Science, Padjadjaran University

\begin{abstract}
Soybeans are one of the plants that require large amounts of phosphorus. The availability of $\mathrm{P}$ is a major limiting factor in its growth and production. Phosphorus is not widely available for plants, so it requires biological fertilizers that contain microorganisms to dissolve phosphorus. This study aims to obtain a dose of compound biofertilizer and $\mathrm{P}$ fertilizer that is effective and can provide the best effect on growth, yield components, and yield of Anjasmoro cultivar soybean plants. The research conducted from March to June 2017 at the Ciparanje Experimental Field, Faculty of Agriculture, University of Padjadjaran, with altitude of 780 meters above sea level. Experiment used Randomized block design that consisted of 9 treatments. There were without biological fertilizers and without $\mathrm{P}$ fertilizer; 100 $\mathrm{kg} /$ ha $\mathrm{P}$ fertilizer $+5 \mathrm{~L} /$ ha biological fertilizer; $100 \mathrm{~kg} / \mathrm{ha} \mathrm{P}$ fertilizer $+8 \mathrm{~L} / \mathrm{ha}$ biological fertilizer; $100 \mathrm{~kg} / \mathrm{ha} \mathrm{P}$ fertilizer + $10 \mathrm{~L} / \mathrm{ha}$ biological fertilizer; $150 \mathrm{~kg} /$ ha fertilizer $\mathrm{P}+5$ L/ha biological fertilizer; P $150 \mathrm{~kg} /$ ha fertilizer + $8 \mathrm{~L} /$ ha biological fertilizer; $150 \mathrm{~kg} /$ ha fertilizer $\mathrm{P}$ $+10 \mathrm{~L} /$ habiological fertilizer. It was repeated three times. The results showed that a combination of phosphorus fertilizer $150 \mathrm{~kg} / \mathrm{ha}$ + biological fertilizer $10 \mathrm{~L} / \mathrm{ha}$ gave were significant effect on plant height and the number of root nodules but it had no effect on plant height, plant dry weight, leaf area index, number of seeds, seed weight, and harvest index.
\end{abstract}

Keywords: Soybean · Biofertilizer • inceptisols

\footnotetext{
Dikomunikasikan oleh Agus Wahyudin

Irwan, A.W.1. T. Nurmala ${ }^{1}$

1Staf Pengajar Fakultas Pertanian Unpad

Korespondensi: a.wawan.irwan@unpad.ac.id
}

Sari. Kedelai merupakan salah satu tanaman yang membutuhkan fosfor dalam jumlah besar. Ketersediaan $\mathrm{P}$ merupakan faktor pembatas utama pada pertumbuhan dan produksinya. Fosfor tidak banyak tersedia untuk tanaman, sehingga dibutuhkan pupuk hayati yang mengandung mikroorganisme untuk dapat melarutkan fosfor. Penelitian ini bertujuan untuk memperoleh dosis pupuk hayati majemuk dan pupuk $P$ yang efektif dan dapat memberikan pengaruh terbaik terhadap pertumbuhan, komponen hasil, dan hasil tanaman kedelai kultivar Anjasmoro. Penelitian dilakukan pada bulan Maret sampai Juni 2017 di Kebun Percobaan Ciparanje, Fakultas Pertanian Universitas Padjadjaran, dengan ketinggian tempat yaitu $\pm 780 \mathrm{mdpl}$. Percobaan dilakukan dengan menggunakan Rancangan Acak Kelompok terdiri dari 9 perlakuan dan diulang tiga kali, adapun perlakuannya yaitu : tanpa pupuk fosfor dan tanpa pupuk hayati; 100 $\mathrm{kg} /$ ha pupuk fosfor; $5 \mathrm{~L} /$ ha pupuk hayati; 100 $\mathrm{kg} /$ hapupuk fosfor $+5 \mathrm{~L} /$ ha pupuk hayati; 100 $\mathrm{kg} /$ ha pupuk fosfor $+8 \mathrm{~L} /$ ha pupuk hayati; 100 $\mathrm{kg} /$ ha pupuk fosfor $+10 \mathrm{~L} / \mathrm{ha}$ pupuk hayati; $150 \mathrm{~kg} /$ ha pupuk fosfor $+5 \mathrm{~L} /$ ha pupuk hayati; $150 \mathrm{~kg} /$ ha pupuk fosfor $+8 \mathrm{~L} /$ ha pupuk hayati dan $150 \mathrm{~kg} /$ ha pupuk fosfor + $10 \mathrm{~L} /$ ha pupuk hayati. Hasil percobaan menunjukkan bahwa kombinasi pupuk fosfor $150 \mathrm{~kg} / \mathrm{ha}+$ pupuk hayati $10 \mathrm{~L} /$ ha memberikan pengaruh nyata terhadap tinggi tanaman dan jumlah bintil akar, namun tidak memberikan pengaruh terhadap tinggi tanaman, bobot kering tanaman, indeks luas daun, jumlah biji per tanaman, bobot biji per tanaman dan indeks panen.

Kata kunci: kedelai $\cdot$ Pupuk hayati - Inceptisols 


\section{Pendahuluan}

Kedelai saat ini masih merupakan komoditas penting bagi masyarakat dan digunakan sebagai bahan dasar pembuatan tempe, tahu, tauco, kecap, dan sebagai bahan campuran pakan ternak. Kedelai berperan penting sebagai sumber protein, karbohidrat dan minyak nabati yang murah dan mudah didapat oleh masyarakat. Setiap $100 \mathrm{~g}$ biji kedelai mengandung 18,10 g lemak; 34,80 g karbohidrat; 10,10 g air; 331,00 kalori; 34,90 protein; dan $227,00 \mathrm{mg}$ kalsium (Direktorat Gizi Depkes RI, 1981). Rachmina dan Putri (2017) menyebutkan produksi kedelai di Indonesia tahun 2017 mencapai 954.997 ton biji kering atau meningkat sebanyak 8.186 ton dibandingkan tahun 2016.

Kebutuhan kedelai terus meningkat sejalan dengan peningkatan jumlah penduduk, peningkatan kesadaran masyarakat akan kecukupan gizi dan perkembangan industri pakan ternak, namun kebutuhan kedelai di dalam negeri masih belum seimbang dengan kemampuan produksinya. Ketidakseimbangan tersebut sudah terjadi dalam kurun waktu yang cukup lama hingga sekarang (Manurung dan Syam'un, 2013).

Ketersediaan kedelai di Indonesia pada tahun 2016 masih sangat rendah, diperkirakan hanya sebanyak 926.000 ton, sedangkan perkiraan kebutuhan kedelai mencapai 2.235.000 ton (Badan Pusat Statistik, 2017). Menurut Neraca Kebutuhan dan Ketersediaan Pangan Tahun 2016 menyebutkan bahwa Indonesia impor kedelai hingga 2.000 ton. Hal tersebut menjadikan Indonesia harus memenuhi kebutuhan kedelai dengan impor $45 \%$ dari kebutuhan kedelai nasional (Mursidah, 2017).

Rendahnya produksi rata-rata kedelai di Indonesia disebabkan oleh beberapa faktor, diantaranya adalah cara bercocok tanam yang dilakukan petani masih kurang tepat, misalnya dalam hal pemupukan (Priambodo et al., 2009). Faktor lain adalah tingkat kesuburan tanah rendah, populasi gulma tinggi, kualitas benih rendah (Misran, 2013). Hasil yang optimal dapat dicapai jika kebutuhan unsur hara setiap tanaman dapat dipenuhi, namun akan menjadi sebaliknya, yaitu tanaman tidak dapat tumbuh normal bahkan mati jika unsur hara dalam tanah tidak tersedia bagi tanaman (Bachtiar dan Waluyo, 2013).

Usaha peningkatan produksi kedelai sudah dilakukan melalui ekstensifikasi (perluasan areal) dan intensifikasi (peningkatan produktivitas), namun hal tersebut belum bisa menutupi kebutuhan kedelai dalam negeri (Priambodo et al., 2009). Upaya lain yang dapat meningkatkan produksi kedelai adalah dengan pemupukan, karena tidak semua tanah cocok untuk pertumbuhan tanaman kedelai. Pada umumnya tanah-tanah pertanian tidak menyediakan semua hara tanaman yang dibutuhkan dalam waktu cepat dan jumlah yang cukup untuk dapat mencapai pertumbuhan optimal (Ratnasari et al., 2015).

Misran (2013) menyatakan bahwa pemberian bahan organik dan pupuk anorganik terutama yang mengandung $\mathrm{N}, \mathrm{P}, \mathrm{K}$, dan unsurunsur mikro sangat baik untuk memperbaiki kondisi fisik dan kimiawi tanah serta menambah unsur hara dalam tanah. Hal ini karena pada pupuk anorganik hanya mengandung beberapa unsur hara walaupun dalam jumlah banyak, sedangkan pupuk organik mengandung unsur hara makro dan mikro yang lebih lengkap meskipun dalam jumlah sedikit sehingga pemakaian pupuk organik dan anorganik secara bersamaan dapat memberikan hara dalam jumlah yang cukup dan berimbang (Iriani dan Handoyo, 2011).

Pemberian pupuk hayati merupakan upaya memperbaiki kondisi lingkungan tanaman dalam hal penyediaan unsur hara, menetralkan $\mathrm{pH}$ tanah dan mengaktifkan jasad renik atau mikroorganisme dalam tanah, sehingga tanah menjadi gembur dan subur. Pupuk hayati mengandung unsur hara makro dan mikro sehingga mampu menyediakan dan meningkatkan nutrisi dan mineral yang sangat diperlukan oleh tanaman (Soverda dan Hermawati, 2009). Selain itu untuk meningkatkan produktivitas tanah dan meningkatkan pertumbuhan tanaman diperlukan masukan dalam bentuk pupuk anorganik yang harus disertai dengan pupuk organik (Irwan dan Wahyudin, 2017).

Aplikasi pupuk hayati seperti bakteri penambat $\mathrm{N}$ (nitrogen) sangat dibutuhkan karena berpotensi meningkatkan kesuburan tanah dan bakteri Endofitik (Misran, 2013). Pupuk hayati merupakan bahan yang mengandung bakteri fungsional yang penambahannya dimaksudkan untuk memfasilitasi penyediaan hara bagi tanaman. Mikroba fungsional yang biasa ditambahkan meliputi bakteri penambat nitrogen, bakteri pelarut fosfor, maupun bakteri penghasil fitohormon 
(Syahriyah, 2014) salah satunya yaitu bakteri Rhizobium.

Kedelai diketahui sebagai tanaman yang mampu bersimbiosis dengan bakteri penambat nitrogen $(\mathrm{N})$ di udara dengan membentuk nodula pada akarnya (Bachtiar dan Waluyo, 2013). Disamping itu pemberiaan Rhizobium sangat diperlukan dengan tujuan untuk meningkatkan jumlah Rhizobium dalam tanah. Mulyani (2006) mengatakan bahwa hubungan antara bakteri Rhizobium dengan akar Leguminosae merupakan simbiosis mutualisme yang saling menguntungkan. Bakteri Rhizobium akan mengikat nitrogen bebas di udara sebagai senyawa zat lemas sehingga dapat dimanfaatkan oleh akar Leguminosae. Rhizobium mendapatkan makanan berupa karbohidrat sebagai sumber energi. Irwan dan Nurmala (2018) menyatakan pupuk hayati mempunyai prospek yang baik untuk dikembangkan dan saat ini semakin diminati oleh petani karena selain ramah lingkungan, juga dapat meningkatkan produktivitas tanaman.

Tanaman kedelai membutuhkan fosfor $(\mathrm{P})$ lebih banyak dibandingkan dengan leguminosa lain. Fosfor merupakan faktor pembatas utama di daerah tropis karena sering diikat oleh unsur aluminium dan besi (Hanum, 2013). Pada tanaman kedelai, unsur fosfor diperlukan untuk aktivitas bintil akar agar terbentuk secara maksimal. Kenyataan ini menunjukkan bahwa diperlukan pupuk fosfor yang cukup agar terjamin proses fiksasi $\mathrm{N}_{2}$ secara maksimal dan menghasilkan biji yang besar. Kekurangan fosfor yang akut dapat memperlambat dan menunda primordia bunga, sehingga biji yang dihasilkan berkerut, hampa, kecambahnya kecil dan matang lebih awal (Jayasumarta, 2012).

Kombinasi yang didapat dari penggunaan pupuk hayati dan pupuk anorganik yaitu dapat menciptakan kondisi tanah (sifat fisik, kimia, dan biologi) lebih baik dan memungkinkan dapat meningkatkan produktivitas tanaman lebih besar dan efisien dibandingkan hanya menggunakan pupuk anorganik saja. Dosis penggunaan pupuk hayati dan pupuk anorganik harus sesuai agar kebutuhan tanaman dapat terpenuhi dengan cukup (Purwanti et al., 2014).

Pada percobaan ini diharapkan dapat memperoleh informasi tentang kombinasi pupuk hayati majemuk dan pupuk fosfor yang terbaik terhadap pertumbuhan dan hasil kedelai pada tanah inceptisol Jatinangor yang miskin hara dan aktivitas mikroorganisme yang rendah.

\section{Bahan dan Metode}

Bahan-bahan yang digunakan pada percobaan ini antara lain: Benih kedelai Anjasmoro, Pupuk hayati majemuk cair dengan kandungan mikroba: Rhizobium sp., Azospirillum sp., Azotobacter sp., Pseudomonas sp., dan Bacillus sp., pupuk urea, pupuk SP-36, pupuk $\mathrm{KCl}$, insektisida, serta fungisida.

Alat-alat yang digunakan antara lain alat pengolah tanah (cangkul dan kored), alat ukur (penggaris, meteran dan jangka sorong), handsprayer, label, gelas ukur, timbangan analitik, kaca pembesar, emrat, ember, germinator, dan alat tulis.

Rancangan percobaan yang digunakan adalah metode eksperimen dengan menggunakan Rancangan Acak Kelompok (RAK) dengan perlakuannya adalah pemberian berbagai dosis pupuk hayati majemuk dan pupuk $\mathrm{P}$, yaitu $\mathbf{A}=$ tanpa pupuk fosfor dan pupuk hayati; $\mathbf{B}=100 \mathrm{~kg} /$ ha pupuk fosfor; $\mathbf{C}=$ $5 \mathrm{~L} /$ ha pupuk hayati; $\mathbf{D}=100 \mathrm{~kg} /$ ha pupuk fosfor $+5 \mathrm{~L} /$ ha pupuk hayati; $\mathbf{E}=100 \mathrm{~kg} / \mathrm{ha}$ pupuk fosfor $+8 \mathrm{~L} /$ ha pupuk hayati; $\mathbf{F}=100$ $\mathrm{kg} /$ ha pupuk fosfor $+10 \mathrm{~L} /$ ha pupuk hayati; G $=150 \mathrm{~kg} / \mathrm{ha}$ pupuk fosfor $+5 \mathrm{~L} / \mathrm{ha}$ pupuk hayati; $\mathbf{H}=150 \mathrm{~kg} /$ ha pupuk fosfor $+8 \mathrm{~L} /$ ha pupuk hayati dan $\mathrm{I}=150 \mathrm{~kg} / \mathrm{ha}$ pupuk fosfor + $10 \mathrm{~L} /$ ha pupuk hayati.

Percobaan ini dilakukan pada tanah Inceptisol Jatinangor dengan pemberian pupuk organik 1 minggu sebelum tanam dengan dosis 2 ton/ha. Pemberian pupuk anorganik dasar dengan cara ditugal dengan dosis $25 \mathrm{~kg} / \mathrm{ha}$ Urea, SP-36 (sesuai dengan perlakuan), dan 100 $\mathrm{kg} / \mathrm{ha} \mathrm{KCl}$, semuanya diberikan pada saat tanam.

Pupuk hayati diberikan sebanyak dua kali yaitu 1MST dan 3 MST dengan disiramkan secara merata pada lahan (daerah perakaran), dosisnya sesuai dengan perlakuan.

Penanaman dilakukan dengan cara ditugal di setiap petak dengan jarak tanam $25 \mathrm{~cm} \times 25$ $\mathrm{cm}$, dengan 2 biji perlubang. Untuk menghindari hama yang menyerang benih di dalam tanah, setiap lubang tanam diberikan Furadan 3G dengan dosis $20 \mathrm{~kg} / \mathrm{ha}$.

Pemeliharaan dilakukan meliputi penyulaman terhadap benih kedelai yang tidak tumbuh; pengairan, dilakukan pada pagi/sore hari dengan alat emrat hingga kapasitas lapang. Penyiangan dilakukan saat tanaman berumur 
20-30 hari setelah tanam karena kondisi gulma relatif banyak. Selain itu, dilakukan pula penggemburan tanah dengan kored. Pengendalian hama dan penyakit dilakukan pada 30-40 HST bila terdapat gejala serangan hama dan penyakit dengan penyemprotan insektisida dan fungisida. Penyemprotan dilakukan pada saat cuaca tidak terlalu panas yaitu pagi atau sore hari.

Panen kedelai dilakukan pada saat sebagian besar daun sudah menguning, tetapi bukan karena serangan hama atau penyakit, lalu gugur, buah mulai berubah warna dari hijau menjadi kuning kecoklatan, atau polong sudah kelihatan tua, batang berwarna kuning agak coklat. Kedelai dipanen pada umur 95 hari, dengan cara memotong pangkal batang menggunakan gunting stek, selanjutnya dikumpulkan dan dijemur dengan sinar matahari menggunakan alas selama 2-3 hari. Hasil panen yang telah kering (sekitar 14\%) kemudian dirontokkan secara manual.

Pengamatan pada percobaan ini meliputi: komponen pertumbuhan, terdiri dari tinggi tanaman, bobot kering tanaman, indeks luas daun (ILD), dan jumlah bintil akar efektif. Pengamatan komponen hasil dan hasil meliputi: jumlah polong isi per tanaman, jumlah biji per tanaman, bobot biji per tanaman, dan indeks panen

\section{Hasil dan Pembahasan}

Tinggi Tanaman. Tinggi tanaman merupakan indikator pertumbuhan yang digunakan untuk mengukur pengaruh lingkungan atau perlakuan yang diterapkan, karena tinggi tanaman merupakan ukuran pertumbuhan yang paling mudah dilihat (Sitompul dan Guritno, 1995) dan merupakan pertumbuhan tanaman fase vegetatif dimana di dalamnya terjadi pembelahan dan pembesaran sel didalam jaringan khusus yang disebut meristem. Sebagaimana dijelaskan oleh Gardner et al., (1991), bahwa meristem ujung menghasilkan sel-sel baru diujung akar atau batang, mengakibatkan tumbuhan bertambah tinggi atau panjang.

Data pengamatan pengaruh pemberian pupuk hayati majemuk dan pupuk fosfor terhadap tinggi tanaman dapat dilihat pada Tabel 1. Hasil analisis lebih lanjut dengan uji jarak berganda Duncan pada taraf 5\% menunjukkan bahwa perlakuan $\mathrm{H}$ (pemberian pupuk hayati majemuk $8 \mathrm{~L} /$ ha dan pupuk fosfor $150 \mathrm{~kg} / \mathrm{ha}$ ) berbeda nyata dengan perlakuan lain, kecuali perlakuan $C$ dan D terhadap tinggi tanaman. Hal ini disebabkan dengan adanya pupuk hayati yang tinggi dapat mendukung pertumbuhan tinggi tanaman. Sesuai dengan hasil penelitian Bachtiar et al., (2013), bahwa varietas Anjasmoro mempunyai respons positif terhadap perlakuan pemberian pupuk hayati ketika pada masa awal pertumbuhan, Rhizobium sudah mampu melakukan pembentukan bintil akar, yaitu sekitar 4-5 hari setelah tanam dan bintil akar dapat mengikat nitrogen dari udara pada umur 10-12 hari setelah tanam sehingga mampu mendukung pertumbuhan tanaman, selain itu diduga karena unsur hara didalam tanah telah mampu menyuplai hara sesuai kebutuhan tanaman, terutama untuk mendukung pertumbuhan tinggi tanaman.

Tabel 1. Pengaruh kombinasi pupuk hayati dan pupuk fosfor terhadap tinggi tanaman 5 MST.

\begin{tabular}{cc}
\hline Perlakuan & Tinggi tanaman $(\mathrm{cm})$ \\
\hline A & $30,36 \mathrm{ab}$ \\
B & $30,83 \mathrm{ab}$ \\
C & $33,10 \mathrm{bc}$ \\
D & $33,46 \mathrm{bc}$ \\
E & $31,30 \mathrm{ab}$ \\
F & $31,43 \mathrm{ab}$ \\
G & $31,23 \mathrm{ab}$ \\
H & $35,73 \mathrm{c}$ \\
I & $28,86 \mathrm{a}$ \\
\hline
\end{tabular}

Bobot Kering. Bobot kering merupakan salah satu indikator pertumbuhan, dimana makin tinggi bobot kering pertanda bahwa tanaman sedang tumbuh. Hasil analisisnya tercantum pada Tabel 2, diketahui bahwa pemberian pupuk hayati dan fosfor tidak berpengaruh nyata. Hal ini diduga dosis pupuk hayati yang belum cukup tinggi untuk meningkatkan bobot kering tanaman sehingga belum membantu secara nyata peningkatan fotosintesis. Peningkatan bobot kering tanaman akibat pemberian pupuk hayati dan fosfor disebabkan oleh mikroba yang terdapat dalam pupuk hayati seperti bakteri penambat nitrogen dan mikroba pelarut fosfor. Menurut Salisbury dan Ross (1995), $\mathrm{N}_{2}$ bebas yang difiksasi secara hayati akan membantu peningkatan fotosintesis, kemudian fotosintat dalam bentuk karbohidrat akan ditranslokasikan keseluruh jaringan tanaman dan selanjutnya akan digunakan untuk menunjang pertumbuhan dan perkembangan organ tanaman. 
Tabel 2. Pengaruh kombinasi pupuk hayati dan pupuk fosfor terhadap bobot kering tanaman.

\begin{tabular}{cc}
\hline Perlakuan & Bobot Kering $(\mathrm{g})$ \\
\hline A & $38,64 \mathrm{a}$ \\
B & $39,00 \mathrm{a}$ \\
C & $39,30 \mathrm{a}$ \\
D & $44,10 \mathrm{a}$ \\
E & $44,46 \mathrm{a}$ \\
F & $38,40 \mathrm{a}$ \\
G & $47,90 \mathrm{a}$ \\
H & $42,30 \mathrm{a}$ \\
I & $32,94 \mathrm{a}$ \\
\hline
\end{tabular}

Indeks Luas Daun. Produksi dan pertumbuhan tanaman dipengaruhi oleh beberapa faktor lingkungan diantaranya suhu, cahaya matahari, kelembaban, dan lainnya yang secara signifikan mempengaruhi organ vegetatif tanaman terutama daun yang berfungsi sebagai penghasil asimilat dan berhubungan erat dengan produksi atau hasil panen. Gardner et al., (1991), menyatakan permukaan daun yang luas dan datar memungkin cahaya matahari dapat ditangkap semaksimal mungkin per satuan volume dan meminimalkan jarak yang harus ditempuh oleh $\mathrm{CO}_{2}$ dari permukaan daun ke kloroplas, maka dengan demikian daun dapat dikatakan sebagai penentu produksi suatu tanaman dan penghasil asimilasi yang bermanfaat bagi pembentukan bunga, buah dan juga biji tanaman.

Indeks Luas Daun (ILD) merupakan parameter yang menunjukkan potensi tanaman melakukan fotosintesis dan juga potensi produktif tanaman di lapangan. Indeks Luas Daun merupakan rasio antar luas daun tanaman terhadap luas tanah, semakin besar luas daun maka akan semakin besar jumlah klorofil yang dihasilkan dan selanjutnya akan disalurkan ke bagian tanaman yang membutuhkan seperti akar dan batang. Produksi dan perluasan daun yang cepat sangat penting pada produksi tanaman budidaya agar dapat memaksimalkan penyerapan cahaya dan asimilasi. Intensitas cahaya matahari sangat mempengaruhi pertumbuhan opimum tanaman dengan luas daun yang berbeda-beda tergantung pada tinggi tanaman dan banyaknya sinar matahari yang diterima oleh tanaman tersebut. Laju asimilasi biasanya maksimal pada indeks luas daun berkisar 3 sampai 5 pada kebanyakan tanaman budidaya (Gardner et al., 1991). Hasil analisis statistik pengaruh pemberian pupuk hayati dan pupuk fosfor terhadap bobot kering tanaman terdapat pada Tabel 3, bahwa pemberian pupuk hayati dan pupuk fosfor menunjukkan hasil yang tidak berbeda nyata terhadap Indeks Luas Daun. Faktor yang mempengaruhi besarnya ILD adalah kerapatan tanam dan penyediaan unsur hara nitrogen (Goldsworthy dan Fischer, 1992).

Hal ini berarti pemberian pupuk hayati dapat menyediakan unsur hara yang terjerap (tidak tersedia) menjadi tersedia kembali dengan bentuan mikro organisme yang ada pada pupuk hayati. Pupuk hayati juga berperan sebagai sumber energi dan makanan mikroba tanah sehingga dapat meningkatkan aktivitas mikroba tersebut dalam penyediaan hara tanaman. Jadi penambahan pupuk hayati di samping sebagai sumber hara bagi tanaman, sekaligus sebagai sumber energi dan hara bagi mikroba (Simanungkalit $d k k ., 2006$ ).

Tabel 3. Pengaruh kombinasi pupuk hayati dan pupuk fosfor terhadap Indeks Luas Daun.

\begin{tabular}{cc}
\hline Perlakuan & Indeks luas daun \\
\hline A & $1,23 \mathrm{a}$ \\
B & $0,91 \mathrm{a}$ \\
C & $1,61 \mathrm{a}$ \\
D & $1,18 \mathrm{a}$ \\
E & $0,77 \mathrm{a}$ \\
F & $1,08 \mathrm{a}$ \\
G & $1,02 \mathrm{a}$ \\
H & $1,44 \mathrm{a}$ \\
I & $1,04 \mathrm{a}$ \\
\hline
\end{tabular}

Jumlah Bintil Akar Efektif. Kedelai berakar tunggang yang pada akarnya terdapat bintil akar berupa koloni Rhizobium yang terbentuk pada umur tanaman 15-20 hari. Bintil akar efektif ditandai dengan adanya warna merah jambu pada bagian dalam bintil. Bintil akar efektif mengindikasikan adanya aktivitas penambatan $\mathrm{N}_{2}$ bebas oleh Rhizobium.

Hasil analisis statistik pengaruh pemberian pupuk hayati dan pupuk fosfor terhadap jumlah bintil akar terdapat pada Tabel 4, diketahui bahwa perlakuan $\mathrm{H}$ (pupuk hayati $8 \mathrm{~L} / \mathrm{ha}+$ pupuk fosfor $150 \mathrm{~kg} / \mathrm{ha}$ ) menghasilkan bintil akar efektif terbanyak yaitu 40,6 buah bintil akar, menunjukkan hasil yang berbeda nyata dibandingkan dengan perlakuan lainnya. Hal ini menunjukkan bahwa perlakuan pupuk hayati dan fosfor efektif sehingga mampu membentuk bintil akar yang mengakibatkan jumlah bintil akar menjadi meningkat.

Pada perlakuan kontrol pembentukan bintil akar rendah, hal ini sesuai dengan 
Gardner et al. (1992), yang mengemukakan bahwa rendahnya populasi Rhizobium menyebabkan kolonisasi Rhizobium pada akar menjadi sangat kecil sehingga tidak mampu melakukan invasi ke dalam bulu akar dan membentuk bintil.

Keberadaan bintil akar dikatakan efektif dengan jumlah 50 bintil/tanaman, sedikitnya bintil akar efektif yang terbentuk pada percobaan ini dipengaruhi oleh pemberian pupuk dan kesesuaian antara inang dan Rhizobium. Berdasarkan hasil penelitian Parwadi (1986), ternyata pengaruh Rhizobium tidak selalu sama terhadap pembentukan bintil, kemampuan fiksasi, dan hasil biji.

Lerouge et al.(1990) menyatakan bahwa bintil akar efektif akan terbentuk bila terdapat kesesuaian antara tanaman inang dengan Rhizobium. Bakteri penambat nitrogen yang terkandung dalam pupuk hayati merupakan Rhizobium tropici yang memiliki kisaran inang luas meliputi tanaman kacang (Phaseolus vulgaris), lamtoro, dan alfalfa, pada percobaan menggunakan tanaman kedelai yang bukan merupakan kisaran inang Rhizobium tropici.

Hal ini menjadi salah satu faktor sedikitnya bintil akar efektif yang terbentuk, namun tidak selalu pertanaman kedelai yang baik diikuti dengan tumbuhnya bintil akar karena pada kenyataannya tanpa ada bintil akar pun tanaman kedelai dapat berproduksi dengan baik (Prihastuti dan Sudaryono, 2008). Keadaan ini disebabkan oleh ketersediaan unsur hara yang cukup, yang berasal dari pemberian pupuk anorganik ataupun inokulasi mikroba penambat nitrogen nonsimbiotik lainnya

Tabel 4. Pengaruh kombinasi pupuk hayati dan pupuk fosfor terhadap jumlah bintil akar efektif.

\begin{tabular}{cc}
\hline Perlakuan & $\begin{array}{c}\text { jumlah bintil akar } \\
\text { efektif (buah) }\end{array}$ \\
\hline A & $12,66 \mathrm{a}$ \\
B & $25,66 \mathrm{ab}$ \\
C & $21,66 \mathrm{ab}$ \\
D & $15,66 \mathrm{a}$ \\
E & $20,66 \mathrm{ab}$ \\
F & $23,66 \mathrm{ab}$ \\
G & $16,66 \mathrm{a}$ \\
H & $40,66 \mathrm{c}$ \\
I & $17,00 \mathrm{a}$ \\
\hline
\end{tabular}

Jumlah Polong Isi per Tanaman. Polong kedelai yang terbentuk dan membesar akan meningkat seiring dengan bertambahnya umur dan jumlah bunga yang terbentuk. Jumlah polong yang terbentuk beragam setiap ketiak daun, sementara jumlah polong yang dapat dipanen tergantung pada varietas kedelai yang ditanam dan dukungan kondisi lingkungan tumbuh. Data analisis statistik pengaruh pemberian pupuk hayati dan pupuk fosfor terhadap jumlah isi polong per tanaman dan \% polong isi terdapat pada Tabel 5. Pemberian pupuk hayati dan pupuk fosfor tidak berpengaruh nyata terhadap jumlah isi polong per tanaman. Rata-rata jumlah polong isi berkisar antara 30,26 - 39,93.

Pembentukan polong tanaman dipengaruhi oleh kondisi dan kandungan media tanam yang digunakan, pupuk $\mathrm{P}$ dibutuhkan tanaman kedelai karena unsur $\mathrm{P}$ dapat mengaktifkan pembentukan polong dan pengisian polong yang masih kosong, serta mempercepat pemasakan buah. Periode terbesar penggunaan $\mathrm{P}$ dimulai pada masa pembentukan polong sampai kira-kira 10 hari sebelum biji berkembang penuh (Silalahi, 2009). Peran P yang diserap tanaman antara lain penting untuk pertumbuhan sel, pembentukan akar halus dan rambut akar, memperkuat tanaman agar tidak mudah rebah memperbaiki kualitas tanaman, pembentukan bunga, buah dan biji serta memperkuat daya tahan terhadap serangan penyakit, sehingga jumlah polong isi akan semakin kuat (Kurniawan et al., 2014).

Unsur hara fosfor sangat berperan pada masa pembentukan polong menurut Silalahi (2009). Hasil penelitian Hanum (2013) mengindikasikan bahwa pemberian pupuk $\mathrm{P}$ pada tanah masam tanpa disertai pemberian pupuk organik menyebabkan pemupukan $\mathrm{P}$ tidak efisien dan tidak efektif.

Pemberian bahan organik terutama pada tanah masam mampu meningkatkan efisiensi pemberian pupuk P. Asam organik yang terkandung pada pupuk organik mampu bertindak sebagai pengkelat senyawa $\mathrm{Al}$, sehingga $\mathrm{P}$ menjadi lebih tersedia. Secara umum dapat dikatakan bahwa bahan organik memperbesar ketersediaan fosfor tanah, melalui hasil dekomposisinya yang menghasilkan asam-asam organik dan $\mathrm{CO}_{2}$. Bahan organik merupakan sumber energi bagi jasad mikro tanah dan tanpa bahan organik semua kegiatan biokimia akan terhenti, efektivitas penyerapan unsur hara juga sangat dipengaruhi oleh kadarnya di dalam tanah.

Rosliani (1997) menjelaskan fosfor merupakan unsur yang paling kritis dibandingkan 
unsur-unsur lainnya bagi tanaman. Kekurangan unsur tersebut dapat menyebabkan tanaman tidak mampu menyerap unsur hara lainnya, meskipun jumlah fosfor yang diangkut tanaman sedikit.

Tabel 5. Pengaruh kombinasi pupuk hayati dan pupuk fosfor terhadap jumlah polong isi per tanaman.

\begin{tabular}{cc}
\hline Perlakuan & $\begin{array}{c}\text { jumlah polong isi per } \\
\text { tanaman (buah) }\end{array}$ \\
\hline A & $33,07 \mathrm{a}$ \\
B & $35,40 \mathrm{a}$ \\
C & $33,20 \mathrm{a}$ \\
D & $30,67 \mathrm{a}$ \\
E & $39,80 \mathrm{a}$ \\
F & $36,93 \mathrm{a}$ \\
G & $38,20 \mathrm{a}$ \\
H & $39,93 \mathrm{a}$ \\
I & $30,27 \mathrm{a}$ \\
\hline
\end{tabular}

Jumlah Biji per Tanaman. Jumlah biji per tanaman menandakan jumlah seluruh biji pada setiap tanaman kedelai. Jumlah biji tanaman yang banyak biasanya akan mempengaruhi hasil produksi yang diperoleh, menurut Wahda et al., (1996) jumlah biji per tanaman yang lebih dari 100 butir, tergolong kedelai yang berpotensi menghasilkan produksi yang tinggi.

Data analisis statistik pengaruh pemberian pupuk hayati dan pupuk fosfor terhadap jumlah biji per tanaman terdapat pada Tabel 6, diketahui bahwa pemberian pupuk hayati dan pupuk fosfor tidak berpengaruh nyata terhadap jumlah biji per tanaman, Damanik et al, (2011) menyatakan bahwa dosis pupuk dalam pemupukan haruslah tepat, artinya dosis tidak terlalu sedikit dan tidak terlalu banyak yang dapat menyebabkan keracunan. Mitsuhashi et al. (2005) menyatakan akumulasi protein dalam biji ditentukan oleh kecukupan $\mathrm{P}$ tanaman, oleh karenanya kekurangan $\mathrm{P}$ pada tanaman akan mengakibatkan rendahnya laju pertumbuhan dan terhambatnya pembentukan nodula.

Hal ini sesuai dengan hasil penelitian Kurniawan et al. (2014) bahwa terjadi peningkatan jumlah biji per tanaman sebanyak 5 persen pada varietas Anjasmoro yang diberi perlakuan pupuk $\mathrm{P}$ jika dibandingkan dengan kontrol. Pemupukan fosfor merupakan suatu keharusan, akan lebih baik jika pemupukan fosfor dikombinasikan dengan pemberian pupuk organik (Damanik et al., 2011). Jumlah biji yang terbentuk pada kedelai merupakan komponen yang sangat menentukan produksi kedelai karena semakin banyak biji yang terbentuk maka semakin tinggi produksi kedelai. Pupuk hayati juga memiliki manfaat dalam efektivitas penggunaan pupuk anorganik.

Bakteri pelarut fosfor dalam pupuk hayati khususnya meningkatkan ketersediaan hara $\mathrm{N}$ dan P dalam tanah sehingga dapat meningkatkan hasil panen (Ratnasari et al., 2015). Hasil tanaman yang baik dapat dicapai bila lingkungan yang mempengaruhi pertumbuhan berimbang dan menguntungkan. Bila satu faktor tersebut tidak seimbang dengan faktor yang lain, maka dapat menekan atau menghentikan pertumbuhan tanaman (Yudhi, 2002). Hasil penelitian Sihaloho dkk. (2015) menunjukan bahwa pemberian pupuk $\mathrm{P}$ juga meningkatkan produksi tanaman legum dari rataan seberat 2,34 g menjadi 3,56 g pada pemberian 1,875 $\mathrm{g} /$ polybag pupuk $\mathrm{P}$.

Tabel 6. Pengaruh kombinasi pupuk hayati dan pupuk fosfor terhadap jumlah biji per tanaman.

\begin{tabular}{cc}
\hline Perlakuan & $\begin{array}{c}\text { jumlah biji per } \\
\text { tanaman }\end{array}$ \\
\hline A & $56,00 \mathrm{a}$ \\
B & $63,60 \mathrm{a}$ \\
C & $58,60 \mathrm{a}$ \\
D & $50,26 \mathrm{a}$ \\
E & $63,66 \mathrm{a}$ \\
F & $64,93 \mathrm{a}$ \\
G & $60,86 \mathrm{a}$ \\
H & $65,60 \mathrm{a}$ \\
I & $51,06 \mathrm{a}$ \\
\hline
\end{tabular}

Bobot Biji per Tanaman. Bobot biji per tanaman adalah berat seluruh biji dari tanaman kedelai. Benih yang telah mengalami kemunduran akan memiliki bobot lebih rendah dibanding benih bobotnya lebih tinggi. Benih yang berukuran besar biasanya akan menjadi benih yang bermutu baik (Perdana et al., 2012).

Data analisis statistik pengaruh pemberian pupuk hayati dan pupuk fosfor terhadap bobot biji per tanaman terdapat pada Tabel 7, diketahui bahwa pemberian pupuk hayati dan pupuk fosfor tidak berpengaruh nyata terhadap bobot biji per tanaman. Rata-rata bobot biji berkisar antara 26,96 - 45,74 g. Menurut Saerong (2008), unsur P dapat meningkatkan kandungan protein dan bobot biji yang selanjutnya akan mempengaruhi hasil tanaman. Ukuran biji yang besar memberikan total hasil biji kering yang tinggi. Menurut Goldworthy dan Fisher (1992) 
pengisian biji berasal dari fotosintat yang dihasilkan setelah pembungaan dan translokasi kembali fotosintat yang tersimpan. Selanjutnya menurut Gardner et al. (1991) sepanjang masa pertumbuhan reproduktif tanaman semusim yang menghasilkan biji menjadikan biji sebagai organ pemanfaatan (sebagai penyimpan cadangan makanan dan perkembangbiakan) yang dominan.

Oleh karena itu, selama pengisian biji fotosintat yang baru terbentuk maupun yang tersimpan dapat digunakan untuk meningkatkan bobot biji. Menurut Soverda dkk. (2007), hasil tanaman yang baik dapat dicapai bila lingkungan yang mempengaruhi pertumbuhan berimbang dan menguntungkan. Bila satu faktor tersebut tidak seimbang dengan faktor yang lain, maka dapat menekan atau menghentikan pertumbuhan tanaman.

Prinsip ini dapat disebut sebagai faktor pembatas, dimana tingkat hasil produksi tidak akan lebih tinggi dari apa yang dapat dicapai oleh tanaman yang tumbuh dalam keadaan dengan faktor-faktor yang paling minimum. Konsep ini sangat penting dan selalu harus diperhitungkan dan dipertimbangkan, dimana tidak hanya penyediaan unsur hara saja yang dapat mempengaruhi pertumbuhan, lingkungan juga dapat mempengaruhi pertumbuhan tanaman kedelai.

Tabel 7. Pengaruh kombinasi pupuk hayati dan pupuk fosfor terhadap bobot biji per tanaman.

\begin{tabular}{cc}
\hline Perlakuan & $\begin{array}{c}\text { bobot biji per } \\
\text { tanaman }(\mathrm{g})\end{array}$ \\
\hline A & $31,00 \mathrm{a}$ \\
B & $34,46 \mathrm{a}$ \\
C & $30,83 \mathrm{a}$ \\
D & $35,21 \mathrm{a}$ \\
E & $33,46 \mathrm{a}$ \\
F & $31,52 \mathrm{a}$ \\
G & $30,69 \mathrm{a}$ \\
H & $35,74 \mathrm{a}$ \\
I & $28,96 \mathrm{a}$ \\
\hline
\end{tabular}

Kurniawan (2014) menyatakan bahwa fosfor merupakan komponen yang diserap dengan cepat selama pertumbuhan vegetatif dan ditranslokasikan dari jaringan vegetatif ke biji setelah pembungaan; meningkatnya hasil pada varietas-varietas kedelai akibat pemberian pupuk $\mathrm{P}$, disebabkan peningkatan laju transportasi bahan kering kebiji akibat pemberian pupuk $\mathrm{P}$ tersebut. Tersedianya asimilat yang cukup pada tanaman akan meningkatkan bobot biji.

Indeks Panen. Indeks panen (IP) adalah rasio hasil bobot kering yang bernilai ekonomi (biji) dengan hasil bobot kering total tanaman. Nilai indeks panen dapat bervariasi dari 0,15 sampai 0,52 dan nilainya akan bergantung pada lama dan laju pertumbuhan sebelum dan sesudah antesis dan pada pembagian berat kering setelah antesis (Goldsworthy dan Fisher, 1992).

Data analisis statistik pengaruh pemberian pupuk hayati dan pupuk fosfor terhadap IP terdapat pada Tabel 8. Pada percobaan ini tidak terjadi pengaruh pemberian pupuk hayati dan pupuk fosfor. Hal ini diduga karena faktor pertumbuhan yaitu luas daun yang rendah sehingga penyerapan sinar matahari berkurang dan fotosintesis tidak dapat berjalan optimal yang mengakibatkan berkurangnya hasil fotosintat untuk pengisisan biji sehingga indeks panen menjadi rendah.

Indeks panen menggambarkan hasil asimilat yang diperoleh tanaman. Nilai IP yang rendah menunjukkan bahwa tanaman tersebut kurang efisien karena hasil fotosintesisnya tidak dapat ditranslokasikan ke organ yang akan dipanen. Tanaman yang mempunyai daun yang lebih luas pada awal pertumbuhan akan lebih cepat tumbuh karena kemampuan menghasilkan fotosintat yang lebih besar memungkinkan membentuk seluruh organ tanaman yang lebih besar kemudian menghasilkan produksi bahan kering yang semakin besar.

Tabel 8. Pengaruh kombinasi pupuk hayati dan pupuk fosfor terhadap indeks panen.

\begin{tabular}{cc}
\hline Perlakuan & Indeks Panen \\
\hline A & $0,445 \mathrm{a}$ \\
B & $0,463 \mathrm{a}$ \\
C & $0,445 \mathrm{a}$ \\
D & $0,401 \mathrm{a}$ \\
E & $0,387 \mathrm{a}$ \\
F & $0,439 \mathrm{a}$ \\
G & $0,442 \mathrm{a}$ \\
H & $0,501 \mathrm{a}$ \\
I & $0,442 \mathrm{a}$ \\
\hline
\end{tabular}

\section{Kesimpulan}

Hasil percobaan menunjukkan bahwa kombinasi pupuk fosfor $150 \mathrm{~kg} / \mathrm{ha}+$ pupuk hayati $10 \mathrm{~L} / \mathrm{ha}$ memberikan perbedaan pengaruh 
dibandingkan dengan perlakuan lainnya terhadap tinggi tanaman dan jumlah bintil akar, namun tidak memberikan pengaruh terhadap tinggi tanaman, bobot kering tanaman, ILD, jumlah biji per tanaman, bobot biji per tanaman dan indeks panen.

\section{Ucapan Terima Kasih}

Ucapan terima kasih ditujukan kepada D. Triastuti, mahasiswa Minat Pangan Fakultas Pertanian Universitas Padjadjaran, yang telah membantu terselenggaranya percobaan ini.

\section{Daftar Pustaka}

Bachtiar, Taufik, dan S.H. Waluyo. 2013. Pengaruh Pupuk Hayati Terhadap Pertumbuhan dan Serapan Nitrogen Tanaman Kedelai (Glycine max. L.) Varietas Mitani dan Anjasmoro. Pusat Aplikasi Teknologi Isotop dan Radiasi. Badan Tenaga Nuklir Nasional. Jakarta. Vol. 16 No.3, Desember 2013: 411-418.

Badan Pusat Statistik. 2017. Produksi Kedelai menurut Provinsi tahun 2013-2017. Penerbit BPS.

Damanik, M. M. B., B. E. Hasibuan, Fauzi, Sarifuddin dan H. Hanum, 2011. Kesuburan Tanah dan Pemupukan. Universitas Sumatera Utara Press, Medan.

Direktorat Gizi DepKes R.I. 1981. Daftar Komposisi Bahan Makanan. Jakarta: Bhratara Karya Aksara.

Gardner, F.P., R.B. Pearce dan R.L. Mitchell. 1991. Fisiologi tanaman budidaya. UI Press. Jakarta.

Goldsworthy dan Fisher. 1992. Fisiologi Tanaman Budidaya Tropic (Terjemahan dari The Physiology of Tropical Fields Crops oleh Tohari). Gadjah mada Univercity Press. Yogyakarta.

Hanum, Chairani. 2013. Pertumbuhan, Hasil, dan Mutu Biji Kedelai dengan Pemberian Pupuk Organik dan Fosfor. Jurusan Agroekoteknologi, Fakultas Pertanian, Universitas Sumatera Utara. J. Agron. Indonesia 41 (3) : 209 - 214.

Iriani, E., dan J. Handoyo. 2011. Perbanyakan Sumber Kedelai Varietas Grobogan di Tingkat Petani dalam Mendukung Ketersediaan Benih di Jawa Tengah. Balai
Pengkajian Teknologi Pertanian Jawa Tengah. Semarang.

Irwan, A.W. dan A. Wahyudin. 2017. Pengaruh Inokulasi Mikoriza Vesikular arbuskula (MVA) dan Pupuk Pelengkap Cair terhadap pertumbuhan, komponen hasil dan Hasil tanaman Kedelai pada tanah Inceptisol Jatinangor. J Kultivasi. 16 (2) : 326-332.ISSN : 1412-4718.

Irwan, A.W. dan T. Nurmala. 2018. Pengaruh Pupuk Hayati dan Pengapuran terhadap Produktivitas Kedelai di Tanah Inceptisol Jatinangor. J Kultivasi. 17 (2) : 656-663.

Jayasumarta dan Darmawati. 2012. Pengaruh Sistem Olah Tanah dan Pupuk P Terhadap Pertumbuhan dan Produksi Tanaman Kedelai (Glycine max L. Merril). Fakultas Pertanian Univ. Muhammadiyah Sumatera Utara. Agrium. 17 (3) : 1-11.

Kurniawan, Shandy., Aslim Rasyad., dan Wardati. 2014. Pengaruh Pemberian Pupuk Posfor Terhadap Pertumbuhan Beberapa Varietas Kedelai (Glycine max (L.) Merril). Agroteknologi, Fakultas Pertanian Univ. Riau. J. Faperta.1(2) : 1-11.

Lerouge, P., P. Roche, C. Faucher, F. Maillet, G. Truchet, J.C. Promé, J. Dénarié. 1990. Symbiotic host-specificity of Rhizobium meliloti isdetermined by a sulfated and acylated glucosamine oligosac-charidesignal. Nature. 344:781-784.

Manurung, J.P. dan E. Syam'un. 2003. Hubungan komponen hasil dengan hasilkedelai (Glycine max (L.) Merr.) yang ditanam pada lahan diolah berbedasistem dan berasosiasi dengan gulma. Jurnal Agrivigor. 3(2):179-188.

Mursidah. 2017. Perkembangan Produksi Kedelai Nasional dan Upaya Pengembangannya (Lanjutan) Di Propinsi Kalimantan Timur. Fakultas Pertanian, J. Univ. Mulawarman, Samarinda. 6(3):22-34.

Misran. 2013. Studi Penggunaan Pupuk Hayati Pada Tanaman Kedelai. Balai Pengkajian Teknologi Pertanian Sumatera Barat. Jurnal Penelitian Pertanian Terapan. 13 (3): 206-210.

Mitsuhashi, N., M. Ohnishi, Y. Sekiguchi, K. Y.U. Kwon, Y.T. Chang, S.K. Chung, Y. Inoue, R.J. Reid, H. Yagisawa, and T. Mimura. 2005. Phytic acid synthesis and vacuolar accumulation in suspensioncultured cells of Catharanthus roseus induced by high concentration of 
inorganic phosphate and cations. Plant Physiol. 138:1607-1614.

Mulyani. 2006.Peranan Fosfor Alam dan Kombinasi Bakteri Pelarut Fosfor dengan Pupuk Kandang dalam Meningkatkan Serapan Hara dan Hasil Kedelai. J Tanah Lingk. 7(2):41-47.

Parwadi. 1986. Pengaruh beberapa Inokulan dan pupuk $\mathrm{N}$ terhadap Pertumbuhan dan Hasil Tanaman Kedelai [Tesis]. Bogor (ID) : Institut Pertanian Bogor.

Perdana, J. Lea, A. Rasyad, dan A. Zuhry. 2012. Pengaruh Beberapa Dosis Pupuk Fosfor (P) Terhadap Mutu Benih Berbagai Kultivar Kedelai (Glycine max L. Merril) Selama Pengisian dan Pemasakan Biji. Fakultas Pertanian Universitas Riau.

Priambodo, Ardi., Bambang Guritno dan Agung Nugroho. 2009. Upaya Peningkatan Pertumbuhan Dan Hasil Tanaman Kedelai (Glycine max) Melalui Aplikasi Mulsa Daun Jati Dan Pupuk Organik Cair. Fakultas Pertanian Unbraw.

Prihastuti dan Sudaryono. 2008. Evaluasi input agen hayati pada budi daya kedelai di lahan kering masam Lampung Tengah. Agrin 12(1): 56-66.

Purwanti, Lutfi., W. Sutari, Kusumiyati. 2014. Pengaruh Konsentrasi Pupuk Hayati Dan Dosis Pupuk N, P, K Terhadap Pertumbuhan Dan Hasil Tanaman Jagung Manis (Zea mays saccharata Sturt.) Kultivar Talenta. Fakultas Pertanian, Univ. Padjadjaran. Agric. Sci. J. Vol. I(4):177-188

Ratnasari, D., M. K. Bangun, R. Iskandar. 2015. Respons Dua Varietas Kedelai (Glycine max (L.) Merrill.) pada Pemberian Pupuk Hayati dan NPK Majemuk. Program Studi Agroekoteknologi, Fakultas Pertanian, USU, Medan. Jurnal Online Agroekoteknologi . Vol.3, No.1 : 276 - 282.

Rachmina, D. dan T.A. Putri. 2017. Menuju Agribisnis Indonesia yang Berdaya Saing. Departemen Agribisnis Fakultas Ekonomi dan Manajemen. IPB.

Rosliani, R. 1997. Pengaruh Pemupukan dengan Pupuk Majemuk Makro Berbentuk Tablet terhadap Pertumbuhan dan hasil Cabai Merah. J. Hort. 7(3).

Saerong. 2008. Pengaruh Pupuk Fosfor dan Kalium Terhadap Pertumbuhan dan Hasil Kacang Tanah di Lahan Kering. Balai
Pengkajian Teknologi Pertanian. Temu Teknis Fungsional Non Peneliti. Malang.

Salisbury, F.B dan C.W. Ross. 1995. Fisiologi Tumbuhan: Jilid III. Terjemahan. Penerbit ITB Bandung.

Sihaloho, N., N. Rahmawati., dan L. A. P. Putri. 2015. Respons Pertumbuhan dan Produksi Tanaman Kedelai Varietas Detam 1 terhadap Pemberian Vermikompos dan Pupuk P. Program Studi Agroekoteknologi, Fakultas Pertanian, USU, Medan. Jurnal Agroekoteknologi.3(4) :1591- 1600.

Silalahi, H. 2009. Pengaruh inokulasi Rhizobium dan pupuk fosfor terhadap pertumbuhan dan produksi kedelai (Glycine max L. Merill). Departemen Budidaya Pertanian, Fakultas Pertanian, Universitas Sumatera Utara. Medan.

Simanungkalit, R. D. M., D. Ardi Suriadikarta, R. Saraswati, DSetyorini, dan W. Hartatik. 2006. Pupuk Organik dan Pupuk Hayati. Balai Besar Litbang Sumberdaya Lahan Pertanian.

Sitompul, S.M. dan B. Guritno.1995. Analisis Pertumbuhan Tanaman. Gadjah Mada University Press. Yogya.

Soverda, Nerty, Mapegau, dan Destri, F. 2007. Pengaruh berbagai kadar air tanah terhadap pertumbuhan dan hasil tanaman kedelai yang diberi mikoriza vesikular arbuskular. Jurnal Agronomi 11(2): 85-90.

Soverda, Nerty dan Tiur Hernawati. 2009. Respon Tanaman Kedelai (Glycine max (L.) Merr.) Terhadap Pemberian Berbagai Konsentrasi Pupuk Hayati. Jurnal Agronomi. 13 (1) : 115-122.

Syahriyah, N. 2014. Pengujian Efektivitas Pupuk Hayati Majemuk Pada Tanaman Kedelai (Glycine max). Departemen Ilmu Tanah dan Sumberdaya Lahan Fakultas Pertanian Institut Pertanian Bogor. Bogor.

Wahda, R., A. Baihaki, R. Setiamihardja dan G. Suyatna. 1996. Variabilitas dan Heretabilitas Laju Akumulasi Bahan Kering Pada Biji Kedelai. Zuriat 7 (2): 92-97.

Yudhi, Rr. H. B. 2002. Respon tanaman kedelai (Glycine max (L.) Merill) Terhadap Pemupukan Fosfor dan Kompos Jerami pada Tanah Ultisol. Program studi ilmu tanah fakultas pertanian. Universitas Bengkulu. Jurnal Ilmu-Ilmu Pertanian Indonesia. 4 (2) : 78-83. 